\title{
Reaching a milestone in pharmaceutical patenting in Brazil
}

\author{
Gabriel Di Blasi*,1 \\ ${ }^{1}$ Di Blasi, Parente \& Associados, Rio de Janeiro/Rio de Janeiro - Brazil \\ *Author for correspondence: gabriel.diblasi@diblasi.com.br
}

\section{"The IAG will effectively help the governmental agencies communicate and produce more concise judgement over pharmaceutical patent examinations"}

First draft submitted: 12 July 2018; Accepted for publication: 17 December 2018; Published online: 11 January 2019 Keywords: ANVISA $\bullet$ backlog $\bullet$ BPTO $\bullet$ BPTO ANVISA cooperation group $\bullet$ double patentability analysis $\bullet$ examina-
tion $\bullet$ GAI $\bullet$ INPI $\bullet$ patent $\bullet$ pharmaceutical patent application procedure in Brazil

Patent protection is a huge step in the innovation chain. It means that the inventors believe their efforts in the search of a new product have reached a point no one else ever has. Although this is impressive in itself, it must be noted that some industries do seem to have to walk some extra miles to reach innovation status.

That is usually the case for the pharmaceutical area. Most consumers are unaware that before reaching the shelves of their drugstores, drug compounds were researched for years, tested in laboratories and submitted to a series of specific regulations for the Research and Development of new drugs set out by governmental bodies - in Brazil, this is the National Health Surveillance Agency - ANVISA. In addition, Brazil has effectively put into force its Biodiversity Law number 13123/15 [1], which means more regulations for this sector will follow, as the researchers usually make use of natural compounds and/or their traditional knowledge, which is an information or practice conducted by natives, traditional communities or traditional farmers, regarding properties or direct or indirect uses associated to genetic heritage.

That said, it is understandable that patent protection of a pharmaceutical product is seen as a moment of glory. After all the development team has been through, it is time to protect and start marketing the product, and essentially, receive the financial return that a patent-protected product is likely to give, especially in the pharmaceutical business. Despite the rightful critique that the patenting of pharmaceutical products in countries considered to be in a state of development like Brazil would essentially restrict the access to health for the general public [2], we are of the opinion that protecting pharmaceutical drugs by patent is one of the main incentives for companies to invest in Research and Development in that area, which in turn leads human-kind to discover the cure for grave diseases.

Having defended the patenting of pharmaceutical compounds in Brazil, it also must be stressed that the issue is a matter of public health. The right to health is discussed in the universal declaration of human rights, specifically in Article 25, which states "Everyone has the right to a standard of living adequate for the health and well-being of himself and of his family, including (... ) medical care and necessary social services" [3]. Also concerning this subject, the World Health Organization and the Office of the United Nations High Commissioner for Human Rights correctly point out that this right depends on and contributes to other rights, such as "the right to benefit from scientific progress and its applications" [4].

On a national level, the Brazilian Constitution holds the promotion of both public health and development in very specific positions. The first is protected by Article 6 [5], which enumerates basic social rights. On the other hand, development is also protected by Article 5, which states the basic principles of the Constitution, and guarantees that the authors of industrial inventions shall have temporary privilege of their use [6]. It should also be mentioned that the very first article of the Brazilian Constitution states that the Brazilian Democracy is founded on the principles of the "dignity of the human person" and the "social values of labor and the free enterprise" [7], which 
also bear undeniable correlations with public health and development, respectively. This can be achieved through a well-balanced, fast-progressing patent system, as well as investments in Research and Development.

The governmental incentives which make the news are usually related to building new laboratories or receiving international prizes, like a Nobel for Medicine, but there is also an invisible investment in governmental framework. Investment in public bodies that make pharmaceutical patents possible are just as essential as any other, if not more so.

In the Brazilian environment, this mix of innovation and public health determines the involvement of both the Brazilian Patent and Trademark Office (BPTO), and ANVISA when it comes to pharmaceutical patents.

It is a shame, though, when the companies face difficulties in the last part of this journey - the patent prosecution procedure. In the case of Brazil, this comes in the form of a huge backlog at the BPTO in the patent applications to be examined. Although, as we shall see, the prosecution curve has been inclining in favor of faster examination over the last few years, it is still clearly an institutional barrier that the BPTO needs to overcome, especially when it comes to pharma patents.

This article hopes to shed light on one of the BPTO's bottle necks, exploring the multiple institutional arrangements that have tried to solve the complex correlation between innovation and public health but in fact resulted in the current backlog; as well as investigating the joint legal solution that will try to reverse that situation.

\section{An article \& its dubious interpretation}

The issue with pharmaceutical patents in Brazil is a complex case involving the interaction of two agencies, namely the BPTO and ANVISA.

The first layer involves Brazilian Intellectual Property Law - BIPL. The Brazilian Law has an article inserted by law number 10196 of 2001, which expresses the following: "Article 229-C: the granting of patent applications for pharmaceutical products or processes will depend on the ANVISA's prior consent" [8]

The addition of such an article in the BIPL resulted in a multiplicity of interpretations about how the prosecution of pharmaceutical patent applications should proceed. After all, two different governmental bodies were now in charge of the procedure that had been exclusive to the BPTO.

It must be noted, however, that ANVISA's role is "to promote the protection of the population's health by executing sanitary control of the production, marketing and use of products and services subject to health regulation, including related (...) technologies" [9]. That is, the public body's main role is related to health, not technology itself, which is merely one of the groups that might affect it.

Nevertheless, the addition of Article 229-C in the BIPL does not expressly state that ANVISA should focus on the population's health. The normalization of how the prosecution of patent applications would continue came with ANVISA's Resolution RDC number 45, in 2008 [10].

Article 4 of the said Resolution explicitly stated that ANVISA would examine pharmaceutical patent applications with respect to requirements for the patentability of the product or process. That is, ANVISA took it upon itself to do what the BPTO had to do. The Public Health Agency's decisions against the patentability of the application could be challenged by an interested party, and the final decision would be sent to the BPTO, which would continue the procedure.

ANVISA would defend the mentioned position by stating that the introduction of the new article granted the public body 'implied powers' to analyze the patentability of patent applications [11]. Needless to say it created a double patentability examination, one of which was conducted by public employees who most likely did not have the knowledge expected to conduct a complex patent application analysis.

In 2009, the Attorney General's Office (AGU) issued a legal opinion (Legal Opinion number 210) [12], against this patent analysis performed by ANVISA, on the grounds that the law which created the public body never gave it this specific attribution in the first place. Despite ANVISA's request for reconsideration, it was not granted and the AGU maintained its position. Although the AGU's opinion is not mandatory, it provides solid ground on legal disputes for cases in which ANVISA would perform patentability analysis. AGU's legal opinion is now being challenged in court, but with the first instance judge denying the plea, chances are relatively low that a new position will arise in the court, as ANVISA has completely changed Resolution number 45 in 2013.

That year, ANVISA issued Resolution RDC number 21 [13], which apparently took into account the AGU's position, revoking parts of its previous Resolution RDC number 45, especially the infamous Article 4, that now state that ANVISA will maintain its focus on the public health aspects of pharmaceutical patent applications. That, 
however, did not stop the public bodies from issuing contradictory opinions on the patentability analysis, which would still occur.

The effects of such policies were clearly foreseen. Interfarma [14], an important Brazilian pharmaceutical association, estimated in 2017 that the backlog might have reached 21,000 pending patent applications. The same association summarizes the serious impacts of this. Companies sell their pharmaceutical patent-pending, without any competition. Whereas, the time frame of more than 10 years for this analysis ends up causing an exclusivity of the exploration of such a drug for the period of over 20 years [8] promoting legal uncertainty.

This is because the BIPL, in its Article 40, sole paragraph, states that the term of an invention patent shall not be less than 10 years; whereas utility model patents cannot be less than 7 years [15].

\section{A new framework: working together to overcome the backlog}

The most recent change, though, occurred in early 2017, when the BPTO and ANVISA issued Joint Ordinance number 01 .

The BPTO-ANVISA Joint Ordinance number 01 was published in April 13, 2017, and went into force in June of the same year [16]. It finally settled the dispute over how Article 229-C of the BIPL should be interpreted. In the ceremony that marked the signing of the Joint Ordinance, the Minister of Industries, Foreign Trade and Services at the time pointed out that the ordinance was a part of the change they wanted to implement on the IP system in Brazil, in a modernization effort [17].

The new framework, which now is in place, states that when a pharmaceutical patent application is filed, the BPTO will proceed with formal examination and, after it is conducted and the applicant requests substantial examination (as the BIPL determines), the Brazilian Office will then forward the application to ANVISA.

ANVISA will then examine the patent application solely with regard to public health. If the product contains a substance forbidden in Brazil, or the pharmaceutical process reaches the same result as a forbidden substance, the patent application will be considered a risk to health. In this scenario, ANVISA will issue a negative technical opinion and the patent application will be shelved.

There is also a possibility that ANVISA considers that the patent application is important for national public health. In this scenario, ANVISA is able to issue an opinion based on the patentability requirements, but it will only serve as a third-party observation. That is, the final decision regarding the requirements of a patent is still in the hands of the BPTO.

If the patent application is neither a risk for public health nor of huge importance for the public health, ANVISA will issue prior consent and return it to the BPTO.

This framework has already proven to be better than the previous ones, as recent cases show ANVISA has limited its analysis to aspects of public health [18]. The Joint Ordinance has shown that it can connect two institutions that, in the recent past, could not be more distant from one another. Recent studies conducted by the BPTO and ANVISA show that, from 2012 to 2017, ANVISA has issued its consent to approximately $70 \%$ of the applications it has analyzed (not considering the numbers not analyzed, the agency's backlog) [19]; whereas, from January to July 2018, prior consent rates have gone up to $82 \%$ [20]. We can only assume that this indicates that the prior consent rates will keep this pace over the years and, as a consequence, the pharma patents backlog will drastically reduce.

In addition to this, an essential component of the Joint Ordinance might make that connection even stronger. The new workflow is not the only thing that Joint Ordinance number 01 innovated on. Its Article 9 foresaw that the BPTO and ANVISA would create an Interinstitutional Articulation Group (IAG) [21], in which members of ANVISA and the BPTO would share technical information and harmonize their understandings on pharmaceutical patents.

This is a huge step, considering that not long ago the public bodies were arguing over who could perform patent examinations. Furthermore, although the governmental entities are divided so that the work can be done in a more specialized way, it must also not be forgotten that the State is an indivisible entity, and therefore having two public bodies issuing different opinions is counter-productive and overall confusing, producing legal uncertainty. The IAG will effectively help the governmental agencies communicate and produce more concise judgement over pharmaceutical patent examinations.

The IAG was created by the BPTO-ANVISA Joint Ordinance number 02, published in November 2017 [22]. The responsibilities given to IAG were (1) to analyze and suggest mechanisms, procedures and formal instruments necessary to articulate the dialogue between ANVISA and the BPTO; and (2) analyze and suggest common 
ground on patentability conditions and technical opinions, in order to minimize discrepancy on evaluations of pharmaceutical patent applications that are important for public health.

IAG will be comprised of three members from each public body. Moreover, the group will be able to invite specialists, researchers and representatives of other public bodies, as well as public or private entities, to participate in meetings when a deeper analysis is considered necessary. There is evidently progress on the transparency of the project; additionally, it demonstrates an approach to lobbying and advocacy practices, which is a growing trend in Brazil and seems to be on the verge of being regulated. It appears that pharmaceutical companies and private agencies will finally have a voice on what used to be a public dispute over territory - a real joint coalition.

The first meeting of the IAG was held on 7 March 2018, and included the chiefs of both ANVISA and the BPTO, as well as representatives of the IP field, both from industry and practitioners. Furthermore, on 26 March 2018 the first technical meeting was held, in which a methodology was decided upon [23].

Of course, the BPTO needs more infrastructure to improve its services and reduce the backlog in all technical areas; for example, hiring more examiners and having the legal capacity to manage its own income earned by the services rendered. However, the cooperation between both the BPTO and ANVISA is also a path to reduce the backlog in the pharmaceutical field.

In fact, after a thorough study conducted by the Brazilian House of Representatives (on the Special Commission on the Innovation Progress and Incorporation of Technology in the Health Industry in Brazil and Abroad), a memo was sent to the Ministry of Industries, Foreign Trade and Services (to which the BPTO is linked until 2018, after which the new Brazilian President for the 2019-2022 term, Jair Bolsonaro, linked the institution to the Ministry of Economy), suggesting those measures along with a few others, such as prioritizing the analysis of pharmaceutical patent applications or highly valuable equipment, to avoid the application of the legal prevision to extend the term of such patents; giving the patent prosecution more transparency and informatization; and signing international cooperation treaties that enable Brazil to make use of the patent examination performed by other IP offices (which means signing PPH agreements that encompass pharmaceutical patent applications) [24].

Even if not all of those measures are adopted, it must be noted that the Brazilian government is working toward the improvement of pharmaceutical business in Brazil. Now is the time for companies to conduct ethical lobbying practices with the Brazilian Federal Executive branch to make sure that those changes actually materialize.

The IAG is a huge institutional promise to overcome the pharmaceutical patent backlog. Recent numbers show that this area is one of the most affected by the Brazilian Office's backlog that takes an average of 13 years to issue a final decision [25]. Certainly, one of the reasons for this delay is the double patentability standards that ruled for years in Brazil, but the IAG might change this scenario for good.

\section{Conclusion}

After years of misinterpretations and discussions, it seems that 2017 and 2018 will be marked in the history of pharmaceutical patents in Brazil as the years when institutions initiate a period of firm, noncontradictory decisions on the patentability of pharmaceutical applications.

This will most likely have an impact on the backlog of pharmaceutical patent applications for good. It is high time the BPTO solved this issue that prevents the pharmaceutical industry from reaching its peak development in Brazil.

Financial \& competing interests disclosure

The author has no relevant affiliations or financial involvement with any organization or entity with a financial interest in or financial conflict with the subject matter or materials discussed in the manuscript. This includes employment, consultancies, honoraria, stock ownership or options, expert testimony, grants or patents received or pending, or royalties.

No writing assistance was utilized in the production of this manuscript.

\section{References}

Papers of special note have been highlighted as: • of interest; $\bullet \bullet$ of considerable interest

1. Law no. 13.123/2015 (Brazilian Biodiversity Law). May (2015). www.planalto.gov.br/ccivil_03/_Ato2015-2018/2015/Lei/L13123.htm (in Portuguese).

2. BARBOSA Denis Borges. Tratado da propriedade intelectual: tomo II (2nd Edition). Lumen Juris. Rio de Janeiro, 1374 (2017)

3. United Nations. The Universal Declaration of Human Rights. www.un.org/en/universal-declaration-human-rights/ 
4. Office of the United Nations High Commissioner for Human Rights; World Health Organization. The Right to Health. Fact Sheet No. 31. www.ohchr.org/Documents/Publications/Factsheet31.pdf

-. The United Nations examines in depth the human right to health, stating that it is not a right to be understood by itself, but rather it must be interpreted according to other rights, such as the right to [develop and benefit from] scientific progress.

5. Constitution of the Federal Republic of Brazil Article 6. http://english.tse.jus.br/arquivos/federal-constitution

6. Constitution of the Federal Republic of Brazil. Article 5, XXIX: http://english.tse.jus.br/arquivos/federal-constitution

7. Constitution of the Federal Republic of Brazil. Article 1: http://english.tse.jus.br/arquivos/federal-constitution

8. Law no. 9.239/1996 (Brazilian Industrial Property Law). Article 229-C. www.planalto.gov.br/ccivil_03/leis/L9279.htm (in Portuguese)

-• The said article was included in the Brazilian Industrial Property Law via provisional measure, which in Brazil is a type of Law submitted by the President.

9. Agencia Nacional De Vigilância Sanitária - ANVISA. http://portal.anvisa.gov.br/english

10. Agencia Nacional De Vigilância Sanitária - ANVISA. RESOLUTION NO. 45/2008 (REVOKED). http://portal.anvisa.gov.br/documents/10181/2718376/RDC_45_2008_COMP.pdf/b736697a-b8d7-4553-8e89-0f713e2a0a9a

11. Advocacia Geral da União. Parecer AGU No. 210/PGF/AE/2009 P. 6, www.agu.gov.br/page/content/detail/id_conteudo/102324 (in Portuguese)

12. Advocacia Geral da União. Parecer AGU No. 210/PGF/AE/2009 P. 6, www.agu.gov.br/page/content/detail/id_conteudo/102324 (in Portuguese).

13. Agencia Nacional De Vigilância Sanitária - ANVISA. Resolution no. 21/2013. (Revoked) http://portal.anvisa.gov.br/documents/33828 1324806/RDC\%2B21.13\%2BAltera\%2Ba\%2BRDC\%2B45.pdf/53261f48-4f5c-4ae7-98d2-a9bfb538570e?version=1.0 (In Portuguese)

14. Associação da Indústria Farmacêutica de Pesquisa - INTERFARMA. www.interfarma.org.br/ (in Portuguese)

15. Law no. 9.239/1996 (Brazilian Industrial Property Law). Article 40 www.planalto.gov.br/ccivil_03/leis/L9279.htm (in Portuguese).

16. BPTO-ANVISA Joint Ordinance no. 01/2017. www.inpi.gov.br

-. The joint ordinance is the first legal measure adopted by BPTO and ANVISA in a joint effort to solve the double pharmaceutical patent analysis issue.

17. ANVISA. "ANVISA E INPI: ACORDO ACELERA ANÁLISE DE PATENTES". https://goo.gl/mbUhgH. (in Portuguese).

18. NERRE THERAPEUTICS LIMITED (GB) PI0307123-5.

19. INPI and ANVISA. "Cronograma para o $1^{\circ}$ semestre de 2018". www.inpi.gov.br/menu-servicos/patente/grupo-de-articulacao-inpi-anvisa (In Portuguese).

-. The document is part of the inter-institutional group's report on pharmaceutical patent applications in Brazil, and contains a series of analysis conducted in order to spot issues and propose solutions on the topic.

20. INPI and ANVISA. "Cronograma para o $2^{\circ}$ semestre de 2018 ”. www.inpi.gov.br/menu-servicos/patente/grupo-de-articulacao-inpi-anvisa. (In Portuguese).

-. The document is part of the inter-institutional group's report on pharmaceutical patent applications in Brazil, and contains a series of analysis conducted in order to spot issues and propose solutions on the topic.

21. BPTO-ANVISA Joint Ordinance no. 01/2017. Article 9.

22. BPTO-ANVISA Joint Ordinance no. www.lex.com.br/legis_27542373_PORTARIA_CONJUNTA_N_2_DE_20_DE_OUTUBRO_DE_2017.aspx (In Portuguese).

- The second joint ordinance effectively creates the inter-institutional group, that is a prior institutional in the efforts to spot and solve the pharmaceutical patent applications bottlenecks.

23. INPI. GRUPO DE ARTICULAÇÃO INTERINSTITUCIONAL INPI-ANVISA (GAI). www.inpi.gov.br/menu-servicos/patente/grupo-de-articulacao-inpi-anvisa. (In Portuguese).

24. Câmara dos Deputados. Brasil. "Camara dos Deputados do Brasil. Comissão Especial Destinada A Estudar O Processo De Inovação E Incorporação Tecnológica No Complexo Produtivo Da Saúde, No Brasil E No Mundo”. Relatório Final. 122-124 https://goo.gl/boe2nj. (in Portuguese).

25. BPTO statistics for 2017. www.inpi.gov.br/noticias/inpi-divulga-material-com-infograficos-sobre-suas-principais-atividades 
